\title{
Putative fossil blood cells reinterpreted as diagenetic structures
}

\author{
Dana E Korneisel ${ }^{\text {Corresp., } 1}{ }^{\text {, Sterling J Nesbitt }}{ }^{1}$, Sarah Werning ${ }^{2}$, Shuhai Xiao ${ }^{1}$ \\ 1 Department of Geosciences, Virginia Polytechnic Institute and State University (Virginia Tech), Blacksburg, VA, United States \\ 2 Department of Anatomy, Des Moines University, Des Moines, lowa, United States \\ Corresponding Author: Dana E Korneisel \\ Email address: danak@vt.edu
}

Red to red-orange spheres in the vascular canals of fossil bone thin sections have been repeatedly reported using light microscopy. Some of these have been interpreted as the fossilized remains of blood cells or, alternatively, pyrite framboids. Here, we assess claims of blood cell preservation within bones of the therizinosauroid theropod Beipiaosaurus inexpectus from the Jehol Lagerstätte. Using Raman spectroscopy, Energy Dispersive X-ray Spectrometry, and Time of Flight Secondary Ion Mass Spectroscopy, we found evidence of high taphonomic alteration of the bone. We also found that the vascular canals in the bone, once purported to contain fossil red blood cell, are filled with a mix of clay minerals and carbonaceous compounds. The spheres could not be analyzed in isolation, but we did not find any evidence of pyrite or heme compounds in the vessels, surrounding bone, or matrix. However, we did observe similar spheres under light microscopy in petrified wood found in proximity to the dinosaur. Consequently, we conclude that the red spheres are most likely diagenetic structures replicated by the clay minerals present throughout the vascular canals. 


\section{Putative fossil blood cells reinterpreted as diagenetic}

\section{2 structures}

3

4 Dana Elaine Korneisel ${ }^{1}$, Sterling James Nesbitt ${ }^{1}$, Sarah Werning ${ }^{2}$, Shuhai Xiao ${ }^{1}$

5

$6 \quad{ }^{1}$ Department of Geosciences, Virginia Tech, Blacksburg, VA, USA

$7 \quad 2$ Department of Anatomy, Des Moines University, Des Moines, IA, USA

8

9 Corresponding Author:

10 Dana Korneisel ${ }^{1}$

111125 Colonel By Dr, Ottawa, ON, K1S 5B6, Canada

12 Email address: dana.korneisel@carleton.ca 


\section{Abstract}

23 Red to red-orange spheres in the vascular canals of fossil bone thin sections have been repeatedly

24 reported using light microscopy. Some of these have been interpreted as the fossilized remains of 25 blood cells or, alternatively, pyrite framboids. Here, we assess claims of blood cell preservation 26 within bones of the therizinosauroid theropod Beipiaosaurus inexpectus from the Jehol

27 Lagerstätte. Using Raman spectroscopy, Energy Dispersive X-ray Spectrometry, and Time of 28 Flight Secondary Ion Mass Spectroscopy, we found evidence of high taphonomic alteration of 29 the bone. We also found that the vascular canals in the bone, once purported to contain fossil red 30 blood cell, are filled with a mix of clay minerals and carbonaceous compounds. The spheres 31 could not be analyzed in isolation, but we did not find any evidence of pyrite or heme 32 compounds in the vessels, surrounding bone, or matrix. However, we did observe similar spheres 33 under light microscopy in petrified wood found in proximity to the dinosaur. Consequently, we 34 conclude that the red spheres are most likely diagenetic structures replicated by the clay minerals 35 present throughout the vascular canals.

\section{Introduction}

38 The Jehol Biota of the Yixian Formation in Northeast China is a Lagerstätte (Muscente et al. 2017; Pan et al. 2014; Zhou 2014), an exceptional site both in the concentration of fossils and in the quality of preservation (Chang 2011; Pan et al. 2013). The lower Cretaceous lacustrine sediments that host this biota are famous for preserving abundant avialians (Chinsamy et al. 2013; Hou et al. 1995; Zhou 2006a; Zhou 2006b) with epidermal outlines including feathers (Ji et al. 2007; Li et al. 2012; Wang et al. 2010; Xu et al. 2003; Xu et al. 2009; Yuan 2000) and a

44 rich array of other vertebrates with soft tissue preservation (Chang et al. 2003). Molecular 45 preservation, including melanosomes with intact melanin, has been observed in fossilized eyes, 
46 hairs, and feathers (Pan et al. 2016; Wogelius et al. 2011) preserved next to bones with fine

47 surficial and histological details (e.g., canaliculi) (O’Connor et al. 2014; Wang et al. 2019; Yao

48 et al. 2002). The specimen examined herein, the holotype (IVPP V11559) of Beipiaosaurus

49 inexpectus, has fine surface preservation of the bone, feather preservation, and has been proposed

50 to contain fossilized red blood cells based on the appearance of red spherical structures in the

51 bone's vascular canals under light microscopy (Yao et al. 2002).

52 Structures similar to those interpreted as red blood cells in B. inexpectus have also been

53 identified as erythrocytes in other fossils since 1907 (Seitz 1907), but the fossilization potential

54 of blood cells became a popular subject at the end of the $20^{\text {th }}$ and into the $21^{\text {st }}$ century (e.g.,

55 Pawlicki \& Nowogrodzka-Zagórska 1998; Schweitzer et al. 2007; Wilby 1993; Yao et al. 2002).

56 A handful of studies explored the idea of fossilizing blood cells more deeply (Kaye et al. 2008;

57 Martill \& Unwin 1997; Schweitzer \& Horner 1999), and some incorporated data on blood cell

58 shape, chemistry, and the effects of desiccation when identifying microstructures in a fossil as

59 blood cells (Bertazzo et al. 2015; Pawlicki \& Nowogrodzka-Zagórska 1998). Most hypothesized

60 fossil red blood cells, however, are unsupported by chemical data (Moodie 1920; Pawlicki \&

61 Nowogrodzka-Zagórska 1998; Plet et al. 2017; Seitz 1907; Wilby 1993; Yao et al. 2002).

62 Here, we analyze the preservation and vascular canal contents of the holotype of $B$.

63 inexpectus. We aim to determine the composition of this specimen's putative blood cells and the

64 degree of diagenetic alteration of the specimen using the following combination of analytical

65 tools: light microscopy, Scanning Electron Microscopy (SEM), Energy Dispersive X-ray

66 Spectroscopy (EDS or EDX), Raman spectroscopy (Raman), and Time of Flight Secondary Ion

67 Mass Spectrometry (TOF-SIMS). Although each analytical tool has limitations, the combined

68 strengths of these tools offer new insights into intra-vascular preservation. 
69 Geological Setting: Beipiaosaurus inexpectus (IVPP V11559) comes from the Sihetun locality

70 of the Yixian Formation. The locality is a protected site within the Beipiao Bird Fossil National

71 Nature Reserve of Liaoning Province, China (Figure 1A,B) (Wang 1998; Xu et al. 1999).

72 In the Sihetun area, the Yixian is composed of two sedimentary and two volcanic units.

73 The Lujiatun Unit is the lowest and consists of coarse-grained sediments. This is succeeded by

74 the lower volcanic unit, the shales and siltstones of the Jianshangou Unit, and then the upper

75 volcanic unit (Jiang et al. 2011; Jiang \& Sha 2007). The tuffaceous claystones and shales of the

76 Jianshangou Unit host $B$. inexpectus as well as many other vertebrate and invertebrate fossils

77 (Chang 2011; Jiang \& Sha 2007; Pan et al. 2013; Zhou 2006b). Radiometrically dated

$78\left({ }^{40} \mathrm{Ar} /{ }^{39} \mathrm{Ar}\right)$ tuffs near the fossil-bearing layer constrain this unit to $124 \mathrm{Ma}$ (Chang et al. 2009) -

$79125 \mathrm{Ma}$ (Figure 1C) (Swisher et al. 2002), consistent with palynological data (Li \& Batten 2007).

80 The Jianshangou Unit is bracketed by the volcanic units, dated at 125-128 Ma (lower volcanic

81 unit) (Chang et al. 2017) and approximately $122 \mathrm{Ma}$ (upper volcanic unit) (Jiang et al. 2011;

82 Wang et al. 2001). At the Sihetun locality, the layer bearing B. inexpectus (beds 25-29 in Wang

83 et al., 1999) underlies a tuff dated between 124.35 and 126.1 Ma by less than $3.5 \mathrm{~m}$ (Figure 1C)

84 (Wang et al. 1999). Based on these dates, the specimen of focus in this study is from the late

85 Barremian or early Aptian age of the Early Cretaceous Period (Chang et al. 2017; Chang et al.

86 2009; Cohen et al. 2013 (updated); He et al. 2006; Jiang \& Sha 2007; Wang et al. 2001).

87

88

89

90

91

92

\section{Materials \& Methods}

All samples examined in this study, as well as slide/sample number, element (if applicable), and analyses performed, are listed in Table 1.

For histological analysis of fossil bone under light microscopy, we re-analyzed the petrographic thin sections of the left humerus of the B. inexpectus holotype (IVPP V11559) 
93 described in Yao et al. (2002) (see Figure 2A for sampling locations). The original thin sections

94 by Yao et al. (2002) were covered in a highly fluorescent epoxy as well as a glass coverslip, and

95 thus were not useful for Raman, EDS, SEM, or TOF-SIMS analysis.

96 For SEM, Raman, and EDS analysis (as well as additional light microscopy examination

97 of histology), we prepared new petrographic thin sections from materials collected during the

98 initial excavation of IVPP V11559 (Yao et al. 2002). These include a fragmentary gastralium and

99 additional fragments of the left humerus from the holotype, as well as petrified wood found in

100 association with this individual. A hand sample containing gastralia and associated matrix from

101 the holotype specimen was sampled directly for TOF-SIMS analysis. Finally, we also prepared

102 thin sections of modern bone for comparison of Raman spectra.

103 a. Petrographic sectioning: To prepare thin sections of B. inexpectus material and

104 petrified wood, we embedded the fragments in Castolite-AC (EP4101polyester casting resin;

105 Eager Polymers, Chicago, IL) catalyzed with MEKP, and then cut $0.5 \mathrm{~mm}$ thick slices on an

106 IsoMet 1000 Precision Sectioning Saw (Buehler, Lake Bluff, IL) using tap water to fill the basin

107 (for lubrication) and approximately $5 \mathrm{~mL}$ of Cool 2 Cutting Fluid (for cooling; Buehler). Before

108 processing each new specimen, we cleaned and dressed the blade using a priming block. We air-

109 dried slices for a minimum of 12 hours. Before mounting, we roughened slice-sized areas on

110 mounting side of plexiglass slides with a 120-grit sanding sponge to improve specimen adhesion.

111 We mounted each slice on a roughened plexiglass slide using Loctite ULTRA Gel Control

112 commercial superglue (Henkel Corp., Bridgewater, NJ). Mounted slices were then ground on a

113 Metaserv 2000 Grinder/Polisher (Buehler) until they were thin enough to view details in

114 transmitted light (approximately $100 \mu \mathrm{m}$ thick). We first ground the specimens using 240 grit

115 until they were $\sim 300 \mu \mathrm{m}$ thick, then 400 grit to $\sim 150 \mu \mathrm{m}$, and finally using 800 grit until the 
116 specimens were transparent enough that their histological features were visible when dry. All

117 specimens prepared for this study were rinsed clean, but their surfaces received no further

118 chemical treatment after grinding (unless otherwise noted), and they were not coverslipped.

119 b. Raman Spectroscopy: Raman spectroscopy is a well-established method in

120 taphonomy (Bernard et al. 2007; Jehlička et al. 2004; Marshall et al. 2012; Thomas et al. 2007;

121 Thomas et al. 2011; Wiemann et al. 2018; Witke et al. 2004). It is useful for assessing the degree

122 of diagenetic alteration to bone (Thomas et al. 2007; Thomas et al. 2011) and evaluating the

123 origin of compounds and structures in fossil material (Marshall et al. 2012; Thomas et al. 2014;

124 Wiemann et al. 2018).

125 We employed Raman spectroscopy to test the alternative interpretation of the putative red

126 blood cells as framboids of iron minerals (Martill \& Unwin 1997), and to assess the quality of

127 bone preservation from a diagenetic perspective. All Raman spectra were obtained from thin

128 sectioned material, and collected on a high-resolution, $800 \mathrm{~mm}$ focal length spectrometer

129 (LabRAM HR800; Horiba Scientific, Kyoto, Japan) with a $785 \mathrm{~nm}$ diode laser at the Virginia

130 Tech Vibrational Spectroscopy Lab. The laser beam was focused on an approximately $8 \mu \mathrm{m}$

131 diameter spot to reduce heat on the sample and points for analysis were chosen using a 50x

132 objective lens. Raman spectral data were collected at $1 / 10$ power $($ maximum power $=150 \mathrm{~mW})$

133 for 5 seconds per collection. Decreased laser power reduces the intensity of Raman peaks, but

134 also lessens laser damage of the specimen. As blank tests, we also took Raman spectra of the

135 plexiglass, epoxy, and superglue used in slide preparation. The relatively thick (100 $\mu \mathrm{m})$ sections

136 and the weak laser power used in the analysis ensured that the Raman data were not

137 contaminated by epoxy or plexiglass signals; this was confirmed by a comparison between

138 sample data and blank data. The spectral resolution is 0.69 wave numbers. Raman spectra were 
139 baselined using the Gaussian baseline correction algorithm in Fityk (Wojdyr 2010) and

140 CrystalSleuth (Laetsch \& Downs 2006). Reference peak positions (e.g., for pyrite and apatite)

141 were obtained from the CrystalSleuth database.

142 c. Energy Dispersive X-ray Spectrometry: To locate vessels exposed on the surface of

143 thin sections and to obtain element maps of vessel-filling material and near-vessel bone, we used

144 a Hitachi TM-3000 Tabletop SEM coupled with a Quantax 70 Energy Dispersive X-ray

145 Spectrophotometer (EDS) system (Hitachi High-Tech America, Inc., Schaumburg, IL). In initial

146 analyses, we left the samples uncoated, but surrounded them with aluminum tape to improve

147 conductivity, and used the Quantax70 to interpret and visualize the EDS data. Based on these

148 preliminary analyses, we identified specimen 2018-L2 (longitudinal section of a gastralium

149 fragment, see Table 1) as the best candidate for quantitative EDS spot analysis due to the 150 abundance of vessels exposed on the surface of the section.

151 We then collected spot analyses from 2018-L2 on an FEI Quanta 600FEG environmental

152 SEM (FEI Company, Hillsboro, OR) with both back scattered electron (BSE) and secondary

153 electron (SE) capability, operating at a voltage of 5-20 kV. The sample was coated in a mixture

154 of gold and palladium and surrounded by aluminum tape to improve conductivity. We used a

155 Bruker EDX to carry out spot analyses of elemental concentrations and to generate additional

156 elemental maps on vessel fills and lacuna fills.

d. Time of Flight - Secondary Ion Mass Spectrometry: Relative to other mass

158 spectrometers for fossil analysis, TOF-SIMS is minimally destructive; it removes only about 1

$159 \mathrm{~nm}$ of surface material and charges material up to $30 \mathrm{~nm}$ deep in the specimen, a depth easily

160 removed with sputtering if further analysis in a spot is desired (Cheng et al. 2006; Debois et al.

161 2007; Touboul et al. 2005). TOF-SIMS creates a map of relative ion abundance across an area of 
162 a specimen, can analyze both organic and inorganic molecules simultaneously, and can detect

163 molecules as well as individual elements with superb spatial precision (Thiel \& Sjövall 2014).

164 To minimize potential contamination from epoxy, we did not embed TOF-SIMS

165 specimens. Instead, we used a hand sample of gastralia from IVPP V11559, which is surrounded

166 by finely laminated mudstone matrix. We ground a fresh edge of a transverse break through one

167 gastralium (section 2018-X3; see Table 1) using 240 grit and then 800 grit sandpaper on the

168 Metaserv 2000 Grinder/Polisher described above. Just prior to TOF-SIMS analysis, a slice

169 approximately $1 \mathrm{~mm}$ thick (including the ground edge) was cut off with a Dremel tool and rinsed

170 with isopropyl alcohol in order to remove any surface contamination from handling the specimen

171 during collection, storage, and processing. Although isopropyl may remove carbonaceous

172 compounds, this step was necessary because IVPP V11559 was not originally collected and

173 handled with chemical analyses in mind. Section 2018-X3 was then mounted on a silicon stub

174 and placed into the vacuum chamber of an IONTOF TOF.SIMS 5 (Iontof GmbH, Munster,

175 Germany). Areas of interest were sputtered with a $2 \mathrm{kV}$ cesium beam for a minimum of 5

176 minutes to reveal a clean surface at depth (Graham \& Gamble 2018; Taylor et al. 2015). Spectra

177 were acquired from the sputtered surfaces using a $30 \mathrm{kV}$ bismuth ion beam (primary species

$178 \mathrm{Bi}^{3+}$ ), as bismuth is not of biological interest and $\mathrm{Bi}^{3+}$ is very precise (Touboul et al. 2005).

179 We calibrated for mass using $\mathrm{C},{ }^{18} \mathrm{O}, \mathrm{O}_{2}, \mathrm{~F}, \mathrm{Na}, \mathrm{C}_{2}, \mathrm{Al}, \mathrm{Si}, \mathrm{P}, \mathrm{Cl},{ }^{37} \mathrm{Cl}, \mathrm{PO}, \mathrm{PO}_{2}$, and $\mathrm{PO}_{3}$.

180 After identifying calibration peaks, we defined the width of each peak and then assigned non-

181 calibration peaks starting at low masses. We aimed for deviation measures (the difference of an

182 observed peak from the expected location for a given secondary ion) below $200 \mathrm{ppm}$ to improve

183 peak assignment accuracy. Components of shouldered peaks (see Green et al. 2006 for

184 comparable peak morphology) were distinguished from one another whenever the IONTOF 
185 TOF.SIMS 5 software was able to separate them, and we placed the boundary at the nadir of the 186 valley or inflection point of the shoulder.

187

188

189

190

191

192

193

194

195

196

197

198

199

200

201

202

203

204

205

206

207

208

\section{Results}

a. Light microscopy: Sections 2018-L1 through 2018-L5 (a series of longitudinal thin sections from a fragment of a gastralium, see Table 1) are roughly rectangular (Figures 2B-D \& 3A-D). The bone growth pattern does not differ substantially in the exterior and interior of the bone, which is expected for gastralia (e.g., Klein et al. 2019).

Sections 2018-L1 through 5 visually resemble sections LJ98B-1 \& LJ98B-4 from Yao et al. (2002) in terms of their vascularization pattern, lacunae with preserved canaliculi, and a diversity of vessel fills. Most vascular canals are longitudinally oriented, but they anastomose laterally and through the depth of the section, connecting otherwise parallel longitudinal canals. Osteocyte lacunae are visible in each of these sections and are generally lenticular in shape (Figures 2B-D \& 3A-D). They are densely distributed throughout the sections (approximately $650 / \mathrm{mm}^{2}$ ) except at the bone margin and directly adjacent to vascular canals. Canaliculi are often visible and the sections have a high visual quality, similar to a modern histological section (Hedges et al. 1995). Vessel fills have a variety of textures and colors, from massive and opaque black to granular and translucent orange (Figure 3A-D). These fills include translucent, redorange spheres located throughout the vascular canals.

The spheres (i.e., purported red blood cells) are most abundant at points where two vascular canals connect (Figure 3D) and near other shapes and textures of vessel fill material, especially translucent orange and red-orange material. The spheres range in color from pale orange to red-orange, overlapping the color range of but never appearing as deeply red as other vessel fills. In some vessels, it is unclear whether the vessel is densely filled with spheres, filled 
209 with blocky grainy material, or a mixture of the two (Figure 3A). The individual spheres range in 210 size from 6 to $15 \mu \mathrm{m}$, but the majority are about $10 \mu \mathrm{m}$ in diameter. In areas where the spheres 211 are sparse and easily distinguished from one another, their external texture appears bumpy, and 212 appears to be composed of 1-3 $\mu \mathrm{m}$ round subunits. These subunits are best visible when 213 adjusting focus through the depth of the section.

214 Sections 2018-X1 and 2018-X2 (see Table 1; not figured) were cut transversely in 215 sequence from a $3.5 \times 1 \mathrm{~mm}$ fragment provided by Dr. Yao. The edges of these slices are gently 216 curved, as they are part of the circular transverse section of another gastralium or small rib 217 fragment. The transverse sections reveal dark-filled osteocyte lacunae with distinct canaliculi, as 218 well as primary osteons. The contents of these osteons' central canals are not as easy to discern 219 in this view; the variation in textures and colors of vessel fill is not apparent and neither are the 220 spheres.

The petrified wood thin section, 2018-1 (Table 1, Figure 4), is a square slice with two 222 zones of carbonate preservation surrounding a zone of silicious preservation. The carbonate 223 zones do not preserve histological detail. Within the silicious zone, however, lines of boxy segments each about $20-40 \mu \mathrm{m}$ long are visible; these are possibly tracheid cells of the xylem.

225 Some of these segments contain dark round structures that range in size from $<5 \mu \mathrm{m}$ to $20 \mu \mathrm{m}$ 226 and are similar in appearance to the purported blood cells in the associated bone (Figure 4, 227 arrowheads).

b. Raman Spectroscopy: Raman spectra acquired from across these specimens are characterized by a complex of peaks around $1000-1700 \mathrm{~cm}^{-1}$. Apatite peaks are visible in most 230 of the Raman spectra, with an average position of $962.4 \mathrm{~cm}^{-1}$ (range: $959.8-965 \mathrm{~cm}^{-1}$; 
231 Supplemental Table 1). Spectra collected from the plexiglass slide, epoxy, and superglue around

232 our specimen had no peak overlap with our sample spectra (see Supplemental Figure 1).

233 We did not observe peaks for pyrite $\left(\mathrm{FeS}_{2}\right)$ or its associated iron oxides, which would

234 occur at wavenumbers below $700 \mathrm{~cm}^{-1}$ (De Faria et al. 1997; Vogt et al. 1983). We also did not

235 observe any of the five marker peaks for heme compounds, which all occur above $1340 \mathrm{~cm}^{-1}$

236 (Asher 1981; Schweitzer et al. 1997).

237

c. Energy Dispersive X-ray Spectrometry:

238

i. Hitachi TM-3000: The most abundant elements in the bone under EDS are phosphorus

239

240

241

242

243

244

245

246

247

248

249

250

251

252

253

and oxygen (Figure 5D,F). The signals from filled vessels differ across the thin section. Some, especially in regions noted under light microscopy to have many spheres, are dominated by aluminum and silicon, indicating the possible presence of clay minerals (Figure 5B,E). At other locations, carbon is concentrated in the vessels and abundant in void spaces and fractures in the bone. Due to the differences in microscopy, we could not positively identify a sphere as identified on a light microscope under SEM. Figure 5B and E-F show that vessel fills differ in composition from the surrounding bone.

ii. FEI Quanta 600FEG: Using area scans of various exposed vessels on 2018-L1, we

found some fills with carbonaceous compositions and others composed of aluminosilicates. The low-chlorine carbon-rich fills were distinguishable from chlorine-rich epoxy infill by their chlorine content. By employing quantitative spot analyses of the aluminosilicate fills, we found aluminum to be, by far, the dominant element, with high magnesium and calcium contents (7.96, 2.85 , and 1.25 atomic $\%$, respectively). Based on a magnesium number of $100(\mathrm{Mg}$ was detected in the spot analyses, but not $\mathrm{Fe})$ and a very low ratio of alkalis to aluminum $((\mathrm{Na}+\mathrm{K}) / \mathrm{Al}=$ 0.106), we identified the aluminosilicates as kaolinite clay minerals (Page et al. 2008).

Peer] reviewing PDF | (2021:09:65573:1:0:NEW 2 Nov 2021) 
254

255

256

257

258

259

260

261

262

263

264

265

266

267

268

269

270

\section{Discussion}

272 The bone of Beipiaosaurus inexpectus (IVPP V11559) is highly chemically altered. Apatite in 273

274 275 276

\section{d. Time of Flight - Secondary Ion Mass Spectrometry:}

The analyzed material is a transversely cut one-mm-thick section of a gastralium

fragment in situ in finely laminated mudstone that also contains a round, orange-colored concretion (2018-X3 in Table 1). The laminations of the mudstone dip between the concretion and the bone. This scan is a composite of 21 serial scan segments that together measure 1500 by $3500 \mu \mathrm{m}$ (Figure 6A-C). This scan shows a clear difference in composition between the bone and its surrounding matrix, with silicates in the matrix and phosphate in bone, and reveals silicates in the pore spaces of the bone visible at this scale (Figure 6, compare D to I).

Carbonaceous compounds are concentrated in the bone and at the contact between the laminated matrix and concretion but are not abundant within the concretion or matrix (Figure 6, J). Iron and manganese oxides are evenly dispersed through the matrix and nearby concretion. Aluminum is most densely concentrated in the concretion. Outside of the concretion, $\mathrm{Al}$ is densest where $\mathrm{Si}$ is also present, except in the matrix densest with $\mathrm{Cl}$. Both ${ }^{35} \mathrm{Cl}$ and ${ }^{37} \mathrm{Cl}$ are concentrated in the bone, but also infiltrate the matrix in contact with the bone (Figure 6F). The concentration of chlorine within the matrix decreases with distance from the bone. Fluorine is abundant throughout the sampled area but is especially concentrated in the bone (Figure $6 \mathrm{H}$ ).

\section{the holotype gastralia has incorporated both fluorite and carbonates, resulting in a Raman peak} position at a relatively low wavenumber (ca. $962 \mathrm{~cm}^{-1}$; Figure 3). This peak is low despite abundant fluorine in the bone (Figure $6 \mathrm{H}$ ), which drives apatite peaks towards higher wavenumbers. Raman peak positions for bioapatite shift higher with the addition of fluorine 
277 through diagenetic alteration. This results in a range of Raman shifts from $962 \mathrm{~cm}^{-1}$ in modern

278 bone (Alligator mississippiensis) and fossil bone with little alteration, to $966 \mathrm{~cm}^{-1}$ in highly

279 altered fossil bone and in fluorapatite (Thomas et al. 2011).

280 The average position for the apatite peaks in our samples is $962.4 \mathrm{~cm}^{-1}$, much closer to 281 unaltered enamel apatite $\left(962 \mathrm{~cm}^{-1}\right)$ than to fluorapatite $\left(966 \mathrm{~cm}^{-1}\right)$. However, TOF-SIMS 282 analysis shows high concentrations of both chlorine and fluorine in Beipiaosaurus bone. There is 283 a gradient in $\mathrm{Cl}$ concentration from the bone into surrounding matrix observed with TOF-SIMS 284 (Figure 6F). The chlorine is likely a component of altered apatite (Keenan 2016), and the 285 diffusion gradient indicates that exchange between the bone and matrix has occurred, despite the 286 low average apatite peak position observed with Raman. Notably, carbonate in the bone has the 287 opposite effect of fluoride, shifting the peak towards lower wavenumbers (Li \& Pasteris 2014;

288 Thomas et al. 2011). Many of our apatite peaks are below $962 \mathrm{~cm}^{-1}$, indicating a considerable 289 carbonate influence on the peak position.

290 The prevalence of diagenetic materials in the vascular canals also suggests that the bones 291 of this fossil are chemically altered. Using EDS and Raman, we observed a high carbon content 292 in the bone and some vessel (pore space) fills but could not distinguish specific carbonaceous 293 compounds. Additionally, we observed carbon compounds both at the permeable contact 294 between the concretion and matrix and in bone using TOF-SIMS analysis (Figure 6J). This 295 implies that at least some of the carbonaceous materials in the pores of the bone are exogenous, 296 either carried in by fluids during diagenesis or present due to post-burial microbial occupation of 297 pore space (e.g., vascular canals) and fractures throughout the bone and matrix. We did not identify pyrite in our sample with Raman or EDS, even though 5-20 $\mu \mathrm{m}$ iron 299 oxide pseudomorphs of framboidal pyrite have been observed in siliciclastic and carbonate 
300 precipitate laminations in sediments of the Jianshangou Unit in the Sihetun area (Hethke et al.

301 2013) and in unlaminated black mudstones at the Sihetun locality (Zhang \& Sha 2012).

302 Additionally, pyrite framboids ranging in size from 5-31 $\mu \mathrm{m}$ are found in association with insect

303 and plant fossils of the Jehol biota (Leng \& Yang 2003; Wang et al. 2012).

304

The complex of Raman peaks at 1212, 1296, 1430,1570, and $1690 \mathrm{~cm}^{-1}$ (Figure 3) fall in

a similar position to peaks identified in previous publications as Raman bands of carbonaceous

306 compounds such as amides (Lee et al. 2017; Morris \& Mandair 2011; Puech et al. 1986) (Figure

3). A similar peak complex has been observed in other spectra obtained from fossil dinosaur 308 bone of various ages (e.g., (Lee et al. 2017; Wang \& Yang 2007). The peaks in this region do not match any of the materials used in processing nor were these materials detected when targeting the specimen, indicating that our spectra are from the sample itself rather than contamination.

311 The peaks do, however, match with the expected positions of photoluminescent bands, an

312 artefact in Raman spectroscopy that is produced by rare earth elements in fossil apatite and the 313 surrounding shale matrix (Culka and Jehlička 2018; Lenz et al. 2015) and we interpret them as

314 such. We recommend that any future Raman spectroscopic analyses of fossil bone carbonaceous

315 compounds or biomolecules target more recently collected specimens (per Pruvost et al. 2007)

316 and employ corrective methods for rare earth element artefact bands (outlined in Culka and 317 Jehlička 2018).

318 We propose that the spheres in the vascular canals of $B$. inexpectus are botryoidal 319 structures consisting of authigenic or diagenetic kaolinite clays (Figure 7). Although we were 320 unable to specifically target the spheres, the EDS and Raman analyses of the vessel fills 321 recovered no evidence of heme or diagenetic products that would support an identity of 322 fossilized red blood cells. 
324 (Figure 4) that was collected with IVPP V11559 and stored with the bone fragments (see Table

325 1). The presence of these spheres in wood contradicts a blood cell hypothesis but is consistent 326 with authigenic mineralization. The most popular alternative hypothesis to other purported 327 erythrocytes with a similar appearance to those studied herein is framboidal pyrite (Kaye et al. 328 2008; Martill \& Unwin 1997). However, we have found no chemical evidence indicative of 329 pyrite or its oxidative products in our samples, aside from iron and manganese oxides $\left(\mathrm{Mg}_{2} \mathrm{O}^{-}\right.$ 330 and $\mathrm{FeO}^{-}$) scattered evenly in low abundance throughout the matrix (detected with TOF-SIMS; 331 see Supplemental Figure 2). The clays detected in IVPP V11559's vascular canals appear to have a variety of habits in addition to spheres. This does not rule out the possibility that former pyrite structures have been replaced by the clays we observed. In fact, kaolinite can form a pseudomorph of pyrite

335 framboids, and the two minerals are often associated (Pollastro 1981). Many other fossils bear 336 similarly sized spheres that resemble those we observed in this study (Moodie 1920; Schweitzer 337 \& Horner 1999; Seitz 1907; Wilby 1993), though only some of these are hypothesized to be red 338 blood cells. We are inclined to interpret these similar spherical structures as indicators of shared 339 traits of diagenetic history across many fossil localities, reflecting similarities in the taphonomic 340 histories of disparate fossil-bearing environments rather than red blood cell preservation.

341 Individual analysis of these similarly appearing structures would be necessary to ascertain their 342 compositions and thus identities.

\section{Conclusions}


345 On the basis of comprehensive analyses conducted herein, we suggest that the purported blood

346 cells in the bones of Beipiaosaurus inexpectus (IVPP V11559) are authigenic or diagenetic

347 structures composed of kaolinite clay. Even though we were unable to sample the chemical

348 composition of individual spheres directly, clay minerals are concentrated in the pore spaces of

349 the bone, in the same areas of the thin sections where the spheres are most abundant. This

350 suggests that the spheres and other vessel fills are some of the many habits clays can take. The

351 presence of similar small, reddish spheres in the associated petrified wood also weakens the

352 blood cell hypothesis. One factor limiting the certainty of our results is that these spheres,

353 unmistakable when viewed under a light microscope, were not confidently identifiable with

354 SEM.

355 To further investigate the nature and origin of these spheres, chemical analyses of

356 dissolved or etched specimens may allow better association between particular vessel fill

357 structures and exogenous kerogen or clay. A more recently collected specimen may also be more

358 informative for studying biomolecular preservation in fossil bone from the Yixian Formation.

\section{Acknowledgements}

361 This work was completed as part of DEK's master's thesis. First, we thank Dr. Jinxian Yao and

362 Dr. Xu Xing at the IVPP for lending us the fossil materials used in this study. We thank Andrei

363 Dolocan at the University of Texas at Austin for his expertise with TOF-SIMS. Many thanks to

364 Charles Farley, Jing Zhao, and Dr. Robert Bodnar of the Virginia Tech Vibrational Spectroscopy

365 lab for their support. We would especially like to acknowledge Mr. Farley's exceptional help to

366 researchers throughout his career, including these authors, and congratulate him on his

367 retirement. We are grateful to Dr. Michelle Stocker for providing samples of modern bone. We 
368 thank Chunchi Liao and Shiying Wang for their help in the field, expertise on B. inexpectus and 369 the Yixian Formation, and for their friendship and hospitality. We are grateful to Dr. Caitlin 370 Colleary and Dr. Qing Tang for helpful conversation, advice, and support during this project. We 371 thank Drs. Bruce Lieberman, Evan Saitta, Craig Marshall, and two anonymous reviewers for 372 insightful commentary and helpful feedback. This work was primarily completed on the 373 traditional unceded land of the Tutelo and Monacan people. Settlers held enslaved laborers in 374 captivity on this land and used their labor to build the institution in which this study was 375 undertaken. 


\section{References}

377 Asher, SA. 1981. Resonance raman spectroscopy of hemoglobin. Methods in Enzymology

378

379

380

381

382

383

384

385

386

387

388

389

390

391

392

393

394

395

396

397

398

399

400

401

402

403

404

405

406

407

408

409

410

411

412

413

414

415

416

417

418

419
76:371-413.

Bernard S, Benzerara K, Beyssac O, Menguy N, Guyot F, Brown Jr GE, and Goffé B. 2007. Exceptional preservation of fossil plant spores in high-pressure metamorphic rocks. Earth and Planetary Science Letters 262:257-272.

Bertazzo S, Maidment SC, Kallepitis C, Fearn S, Stevens MM, and Xie H-n. 2015. Fibres and cellular structures preserved in 75-million-year-old dinosaur specimens. Nature Communications 6:7352.

Chang MM. 2011. The Jehol Fossils: The Emergence of Feathered Dinosaurs, Beaked Birds and Flowering Plants. Academic Press. Shanghai: Shanghai Scientific and Technical Publishers.

Chang MM, Chen PJ, Wang YQ, and Wang Y. 2003. The Jehol Biota: The Emergence of Feathered Dinosaurs, Beaked Birds, and Flowering Plants. Shanghai: Shanghai Scientific \& Technical Publishers.

Chang SC, Gao K-Q, Zhou C-F, and Jourdan F. 2017. New chronostratigraphic constraints on the Yixian Formation with implications for the Jehol Biota. Palaeogeography, Palaeoclimatology, Palaeoecology 487:399-406.

Chang SC, Zhang H, Renne PR, and Fang Y. 2009. High-precision ${ }^{40} \mathrm{Ar} /{ }^{39} \mathrm{Ar}$ age for the Jehol Biota. Palaeogeography, Palaeoclimatology, Palaeoecology 280:94-104.

Cheng J, Wucher A, and Winograd N. 2006. Molecular depth profiling with cluster ion beams. The Journal of Physical Chemistry B 110:8329-8336.

Chinsamy A, Chiappe LM, Marugán-Lobón J, Chunling G, and Fengjiao Z. 2013. Gender identification of the Mesozoic bird Confuciusornis sanctus. Nature Communications $4: 1381$.

Cohen KM, Finney SC, Gibbard PL, and Fan J-X. 2013 (updated 2021). The ICS international chronostratigraphic chart. Episodes 36:199-204.

Culka A and Jehlička J. 2018. Sequentially shifted excitation: A tool for suppression of laser - induced fluorescence in mineralogical applications using portable Raman spectrometers. Journal of Raman Spectroscopy 49(3):526-537.

De Faria D, Venâncio Silva S, and De Oliveira M. 1997. Raman microspectroscopy of some iron oxides and oxyhydroxides. Journal of Raman Spectroscopy 28:873-878.

Peer) reviewing PDF | (2021:09:65573:1:0:NEW 2 Nov 2021) 
420

421

422

423

424

425

426

427

428

429

430

431

432

433

434

435

436

437

438

439

440

441

442

443

444

445

446

447

448

449

450

451

452

453

454

455

456

457

458

459

460

461

462

463

464

465

Debois D, Brunelle A, and Laprévote O. 2007. Attempts for molecular depth profiling directly on a rat brain tissue section using fullerene and bismuth cluster ion beams. International Journal of Mass Spectrometry 260:115-120.

Graham DJ, and Gamble LJ. 2018. Dealing with image shifting in 3D ToF-SIMS depth profiles. Biointerphases 13:06E402.

Green F, Gilmore I, and Seah M. 2006. TOF-SIMS: Accurate mass scale calibration. Journal of the American Society for Mass Spectrometry 17:514-523.

He H, Wang X, Zhou Z, Jin F, Wang F, Yang L, Ding X, Boven A, and Zhu R. 2006. ${ }^{40} \mathrm{Ar} /{ }^{39} \mathrm{Ar}$ dating of Lujiatun bed (Jehol Group) in Liaoning, northeastern China. Geophysical Research Letters 33.

Hedges RE, Millard AR, and Pike A. 1995. Measurements and relationships of diagenetic alteration of bone from three archaeological sites. Journal of Archaeological Science 22:201-209.

Hethke M, Fürsich FT, Jiang B, and Pan Y. 2013. Seasonal to sub-seasonal palaeoenvironmental changes in Lake Sihetun (Lower Cretaceous Yixian Formation, NE China). International Journal of Earth Sciences 102:351-378.

Hou L-h, Zhou Z, Martin LD, and Feduccia A. 1995. A beaked bird from the Jurassic of China. Nature 377:616.

Jehlička J, Jorge Villar S, and Edwards H. 2004. Fourier transform Raman spectra of Czech and Moravian fossil resins from freshwater sediments. Journal of Raman Spectroscopy 35:761-767.

Ji SA, Ji Q, Lü J, and Yuan C. 2007. A new giant compsognathid dinosaur with long filamentous integuments from Lower Cretaceous of Northeastern China. Acta Geologica Sinica 81:815.

Jiang B, Fürsich FT, Sha J, Wang B, and Niu Y. 2011. Early Cretaceous volcanism and its impact on fossil preservation in Western Liaoning, NE China. Palaeogeography, Palaeoclimatology, Palaeoecology 302:255-269.

Jiang B, and Sha J. 2007. Preliminary analysis of the depositional environments of the Lower Cretaceous Yixian Formation in the Sihetun area, western Liaoning, China. Cretaceous Research 28:183-193.

Kaye TG, Gaugler G, and Sawlowicz Z. 2008. Dinosaurian soft tissues interpreted as bacterial biofilms. PLOS ONE 3:e2808.

Keenan SW. 2016. From bone to fossil: A review of the diagenesis of bioapatite. American Mineralogist 101:1943-1951.

Peer) reviewing PDF | (2021:09:65573:1:0:NEW 2 Nov 2021) 
466

467

468

469

470

471

472

473

474

475

476

477

478

479

480

481

482

483

484

485

486

487

488

489

490

491

492

493

494

495

496

497

498

499

500

501

502

503

504

505

506

507

508

509

510

511

Klein N, Canoville A, and Houssaye A. 2019. Microstructure of vertebrae, ribs, and gastralia of Triassic sauropterygians - New insights into the microanatomical processes involved in aquatic adaptations of marine reptiles. The Anatomical Record 302:1770-1791.

Laetsch T, and Downs R. 2006. Software For Identification and Refinement of Cell Parameters From Powder Diffraction Data of Minerals Using the RRUFF Project and American Mineralogist Crystal Structure Databases. 19th General Meeting of the International Mineralogical Association. Kobe, Japan.

Lee YC, Chiang CC, Huang PY, Chung CY, Huang TD, Wang CC, Chen CI, Chang RS, Liao $\mathrm{CH}$, and Reisz RR. 2017. Evidence of preserved collagen in an Early Jurassic sauropodomorph dinosaur revealed by synchrotron FTIR microspectroscopy. Nature Communications 8:14220.

Leng Q, and Yang H. 2003. Pyrite framboids associated with the Mesozoic Jehol Biota in northeastern China: Implications for microenvironment during early fossilization. Progress in Natural Science 13:206-212.

Lenz C, Nasdala L, Talla D, Hauzenberger C, Seitz R, and Kolitsch U. 2015. Laser-induced REE3+ photoluminescence of selected accessory minerals - An "advantageous artefact" in Raman spectroscopy. Chemical Geology 415:1-16.

Li J, and Batten DJ. 2007. Palynological evidence of an Early Cretaceous age for the Yixian Formation at Sihetun, western Liaoning, China. Cretaceous Research 28:333-338.

Li Q, Gao K-Q, Meng Q, Clarke JA, Shawkey MD, D’Alba L, Pei R, Ellison M, Norell MA, and Vinther J. 2012. Reconstruction of Microraptor and the evolution of iridescent plumage. Science 335:1215-1219.

Li Z, and Pasteris JD. 2014. Tracing the pathway of compositional changes in bone mineral with age: Preliminary study of bioapatite aging in hypermineralized dolphin's bulla. Biochimica et Biophysica Acta (BBA)-General Subjects 1840:2331-2339.

Marshall AO, Wehrbein RL, Lieberman BS, and Marshall CP. 2012. Raman spectroscopic investigations of Burgess Shale-type preservation: a new way forward. Palaios 27:288292.

Martill DM, and Unwin DM. 1997. Small spheres in fossil bones: blood corpuscles or diagenetic products? Palaeontology 40:619-624.

Moodie RL. 1920. Concerning the fossilization of blood corpuscles. The American Naturalist 54:460-464.

Morris MD, and Mandair GS. 2011. Raman assessment of bone quality. Clinical Orthopaedics Related Research ${ }^{\circledR}$ 469:2160-2169.

Peer] reviewing PDF | (2021:09:65573:1:0:NEW 2 Nov 2021) 
512

513

514

515

516

517

518

519

520

521

522

523

524

525

526

527

528

529

530

531

532

533

534

535

536

537

538

539

540

541

542

543

544

545

546

547

548

549

550

551

552

553

554

555

556

Muscente AD, Schiffbauer JD, Broce J, Laflamme M, O'Donnell K, Boag TH, Meyer M, Hawkins AD, Huntley JW, McNamara M, MacKenzie LA, Stanley GD, Hinman NW, Hofmann MH, and Xiao S. 2017. Exceptionally preserved fossil assemblages through geologic time and space. Gondwana Research 48:164-188. 10.1016/j.gr.2017.04.020

O’Connor JK, Wang M, Zheng XT, Wang XL, and Zhou ZH. 2014. The histology of two female Early Cretaceous birds. Vertebrata Pal Asiatica 52:112-128.

Page A, Gabbott SE, Wilby PR, and Zalasiewicz JA. 2008. Ubiquitous Burgess Shale-style "clay templates" in low-grade metamorphic mudrocks. Geology 36:855-858.

Pan Y, Sha J, and Fuersich FT. 2014. A model for organic fossilization of the Early Cretaceous Jehol Lagerstätte based on the taphonomy of "Ephemeropsis trisetalis". Palaios 29:363377.

Pan Y, Sha J, Zhou Z, and Fürsich FT. 2013. The Jehol Biota: definition and distribution of exceptionally preserved relicts of a continental Early Cretaceous ecosystem. Cretaceous Research 44:30-38.

Pan Y, Zheng W, Moyer AE, O'Connor JK, Wang M, Zheng X, Wang X, Schroeter ER, Zhou Z, and Schweitzer MH. 2016. Molecular evidence of keratin and melanosomes in feathers of the Early Cretaceous bird Eoconfuciusornis. Proceedings of the National Academy of Sciences 113:E7900-E7907.

Pawlicki R, and Nowogrodzka-Zagórska M. 1998. Blood vessels and red blood cells preserved in dinosaur bones. Annals of Anatomy-Anatomischer Anzeiger 180:73-77.

Plet C, Grice K, Pagès A, Verrall M, Coolen MJ, Ruebsam W, Rickard WD, and Schwark L. 2017. Palaeobiology of red and white blood cell-like structures, collagen and cholesterol in an ichthyosaur bone. Scientific Reports 7:13776.

Pollastro RM. 1981. Authigenic kaolinite and associated pyrite in chalk of the Cretaceous Niobrara Formation, eastern Colorado. Journal of Sedimentary Research 51:553-562.

Pruvost M, Schwarz R, Correia VB, Champlot S, Braguier S, Morel N, Fernandez-Jalvo Y, Grange T, and Geigl E-M. 2007. Freshly excavated fossil bones are best for amplification of ancient DNA. Proceedings of the National Academy of Sciences 104:739-744.

Puech PF, Dhamelincourt P, Taieb M, and Serratrice C. 1986. Laser Raman microanalysis of fossil tooth enamel. Journal of Human Evolution 15:13-19.

Schweitzer MH, and Horner JR. 1999. Intravascular microstructures in trabecular bone tissues of Tyrannosaurus rex. Annales de Paléontologie: Elsevier. p 179-192.

Peer] reviewing PDF | (2021:09:65573:1:0:NEW 2 Nov 2021) 
557

558

559

560

561

562

563

564

565

566

567

568

569

570

571

572

573

574

575

576

577

578

579

580

581

582

583

584

585

586

587

588

589

590

591

592

593

594

595

596

597

598

599

600

601

602

Schweitzer MH, Marshall M, Carron K, Bohle DS, Busse SC, Arnold EV, Barnard D, Horner J, and Starkey JR. 1997. Heme compounds in dinosaur trabecular bone. Proceedings of the National Academy of Sciences 94:6291-6296.

Schweitzer MH, Wittmeyer JL, and Horner JR. 2007. Soft tissue and cellular preservation in vertebrate skeletal elements from the Cretaceous to the present. Proceedings of the Royal Society B: Biological Sciences 274:183-197. 10.1098/rspb.2006.3705

Seitz ALL. 1907. Vergleichende studien über den mikroskopischen knochenbau fossiler und rezenter reptilien und dessen bedeutung für das wachstum und umbildung des knochengewebes im allgemein. Verhandlungen der Kaiserlich LeopoldinischCarolinischen Deutschen Akademie der Naturforscher 87.

Swisher C, Wang X, Zhou Z, Wang Y, Jin F, Zhang J, Xu X, Zhang F, and Wang Y. 2002. Further support for a Cretaceous age for the feathered-dinosaur beds of Liaoning, China: New ${ }^{40} \mathrm{Ar} /{ }^{39} \mathrm{Ar}$ dating of the Yixian and Tuchengzi Formations. Chinese Science Bulletin 47:136-139.

Taylor AJ, Graham DJ, and Castner DG. 2015. Reconstructing accurate ToF-SIMS depth profiles for organic materials with differential sputter rates. Analyst 140:6005-6014.

Thiel V, and Sjövall P. 2014. Time-of-flight secondary ion mass spectrometry (TOF-SIMS): Principles and practice in the biogeosciences. Analytical Techniques in Geosciences $4: 122$.

Thomas DB, Fordyce RE, Frew RD, and Gordon KC. 2007. A rapid, non-destructive method of detecting diagenetic alteration in fossil bone using Raman spectroscopy. Journal of Raman Spectroscopy 38:1533-1537.

Thomas DB, McGoverin CM, Fordyce RE, Frew RD, and Gordon KC. 2011. Raman spectroscopy of fossil bioapatite - A proxy for diagenetic alteration of the oxygen isotope composition. Palaeogeography, Palaeoclimatology, Palaeoecology 310:62-70.

Thomas DB, Nascimbene PC, Dove CJ, Grimaldi DA, and James HF. 2014. Seeking carotenoid pigments in amber-preserved fossil feathers. Scientific Reports 4:5226.

Touboul D, Kollmer F, Niehuis E, Brunelle A, and Laprévote O. 2005. Improvement of biological time-of-flight-secondary ion mass spectrometry imaging with a bismuth cluster ion source. Journal of the American Society for Mass Spectrometry 16:1608-1618.

Vogt H, Chattopadhyay T, and Stolz H. 1983. Complete first-order Raman spectra of the pyrite structure compounds $\mathrm{FeS}_{2}, \mathrm{MnS}_{2}$ and $\mathrm{SiP}_{2}$. Journal of physics and chemistry of solids 44:869-873.

Wang B, Zhao F, Zhang H, Fang Y, and Zheng D. 2012. Widespread pyritization of insects in the Early Cretaceous Jehol Biota. Palaios 27:707-711.

Peer) reviewing PDF | (2021:09:65573:1:0:NEW 2 Nov 2021) 
603

604

605

606

607

608

609

610

611

612

613

614

615

616

617

618

619

620

621

622

623

624

625

626

627

628

629

630

631

632

633

634

635

636

637

638

639

640

641

642

643

644

645

646

647

Wang J, Hao X, Kundrát M, Liu Z, Uesugi K, Jurašeková Z, Guo B, Hoshino M, Li Y, and Monfroy Q. 2019. Bone tissue histology of the Early Cretaceous bird Yanornis: evidence for a diphyletic origin of modern avian growth strategies within Ornithuromorpha. Historical Biology:1-13.

Wang SS, Hu HG, Li PS, and Wang YQ. 2001. Further discussion on the geologic age of Sihetun vertebrate assemblage in western Liaoning, China: evidence from Ar-Ar dating. Acta Petrolei Sinica 17:663-668.

Wang X-L. 1998. Stratigraphic sequence and vertebrate-bearing beds of the lower part of the Yixian Formation in Sihetun and neigh-boring area, western Liaoning, China. Vertebrata Pal Asiatica 36:81-101.

Wang X, Wang Y, Jin F, Xu X, Wang Y, Zhang J, Zhang F, Tang Z, Li C, and Gu G. 1999. The Sihetun fossil vertebrate assemblage and its geological setting of western Liaoning, China. Palaeoworld 11:310-327.

Wang Y, Dong L, and Evans SE. 2010. Jurassic-Cretaceous herpetofaunas from the Jehol associated strata in NE China: evolutionary and ecological implications. Bulletin of the Chinese Academy of Sciences 24:76-79.

Wang Y, and Yang Q. 2007. Raman Spectra of different done part of fossil dinosaurs. The Journal of Light Scattering 2.

Wiemann J, Yang T-R, and Norell MA. 2018. Dinosaur egg colour had a single evolutionary origin. Nature 563:555.

Wilby PR. 1993. The role of organic matrices in post-mortem phosphatization of soft-tissues. Kaupia : Darmstädter Beiträge zur Naturgeschichte 2:99-113.

Witke K, Götze J, Rößler R, Dietrich D, and Marx G. 2004. Raman and cathodoluminescence spectroscopic investigations on Permian fossil wood from Chemnitz-a contribution to the study of the permineralisation process. Spectrochimica Acta Part A: Molecular Biomolecular Spectroscopy 60:2903-2912.

Wogelius R, Manning P, Barden H, Edwards N, Webb S, Sellers W, Taylor K, Larson P, Dodson $\mathrm{P}$, and You H. 2011. Trace metals as biomarkers for eumelanin pigment in the fossil record. Science 333:1622-1626.

Wojdyr M. 2010. Fityk. Journal of Applied Crystallography 43:1126-1128.

Xu X, Cheng Y, Wang X, and Chang C. 2003. Pygostyle-like Structure from Beipiaosaurus (Theropoda, Therizinosauroidea) from the Lower Cretaceous Yixian Formation of Liaoning, China. Acta Geologica Sinica - English Edition 77:294-298.

Peer] reviewing PDF | (2021:09:65573:1:0:NEW 2 Nov 2021) 
$648 \mathrm{Xu} \mathrm{X}$, Tang Z, and Wang X. 1999. A therizinosauroid dinosaur with integumentary structures

649

650

651

652

653

654

655

656

657

658

659

660

661

662

663

664

665

666

667

668

669

670

671

672

673
Xu X, Zheng X, and You H. 2009. A new feather type in a nonavian theropod and the early evolution of feathers. Proceedings of the National Academy of Sciences 106:832-834.

Yao J, Zhang Y, and Tang Z. 2002. Small Spheres Preserved in a Therizinosauroid Dinosaur's Blood Vessels from Northeast China. Acta Scientiarum Naturalium 38(2) 221-225.

Yuan W. 2000. A new salamander (Amphibia: Caudata) from the Early Cretaceous Jehol biota. Vertebrata Pal Asiatica 38:100-103.

Zhang X, and Sha J. 2012. Sedimentary laminations in the lacustrine Jianshangou Bed of the Yixian Formation at Sihetun, western Liaoning, China. Cretaceous Research 36:96-105.

Zhou Z. 2006a. Adaptive radiation of the Jehol Biota and its evolutionary ecological background. In: Rong J, Fang Z, Zhou Z, Zhan R, Wang X, and YUan X, eds. Originations and radiations-evidences from the Chinese fossil record. Beijing, China: Science Press, 705732, 943-945.

Zhou Z. 2006b. Evolutionary radiation of the Jehol Biota: chronological and ecological perspectives. Geological Journal 41:377-393.

Zhou Z. 2014. The Jehol Biota, an Early Cretaceous terrestrial Lagerstätte: new discoveries and implications. National Science Review 1:543-559. 


\section{Figure 1}

Geographic and stratigraphic setting of Beipiaosaurus inexpectus (IVPP V11559)

Figure 1. Geographic and stratigraphic setting. A: Map of China with box denoting the area enlarged in (B). B: The Sihetun locality (black square) in Liaoning Province. C: Stratigraphic column of the Yixian Formation at Sihetun, showing the stratigraphic horizon of the holotype specimen of Beipiaosaurus inexpectus (marked as “D”). Redrawn from Yao et al. (2002) and field observations. This section is approximately 15 meters from the original collection site and is now covered by new construction. Tuff thicknesses vary laterally. D: Detailed stratigraphy of the fossil horizon of the holotype specimen of Beipiaosaurus inexpectus. Drawn from field observations. 


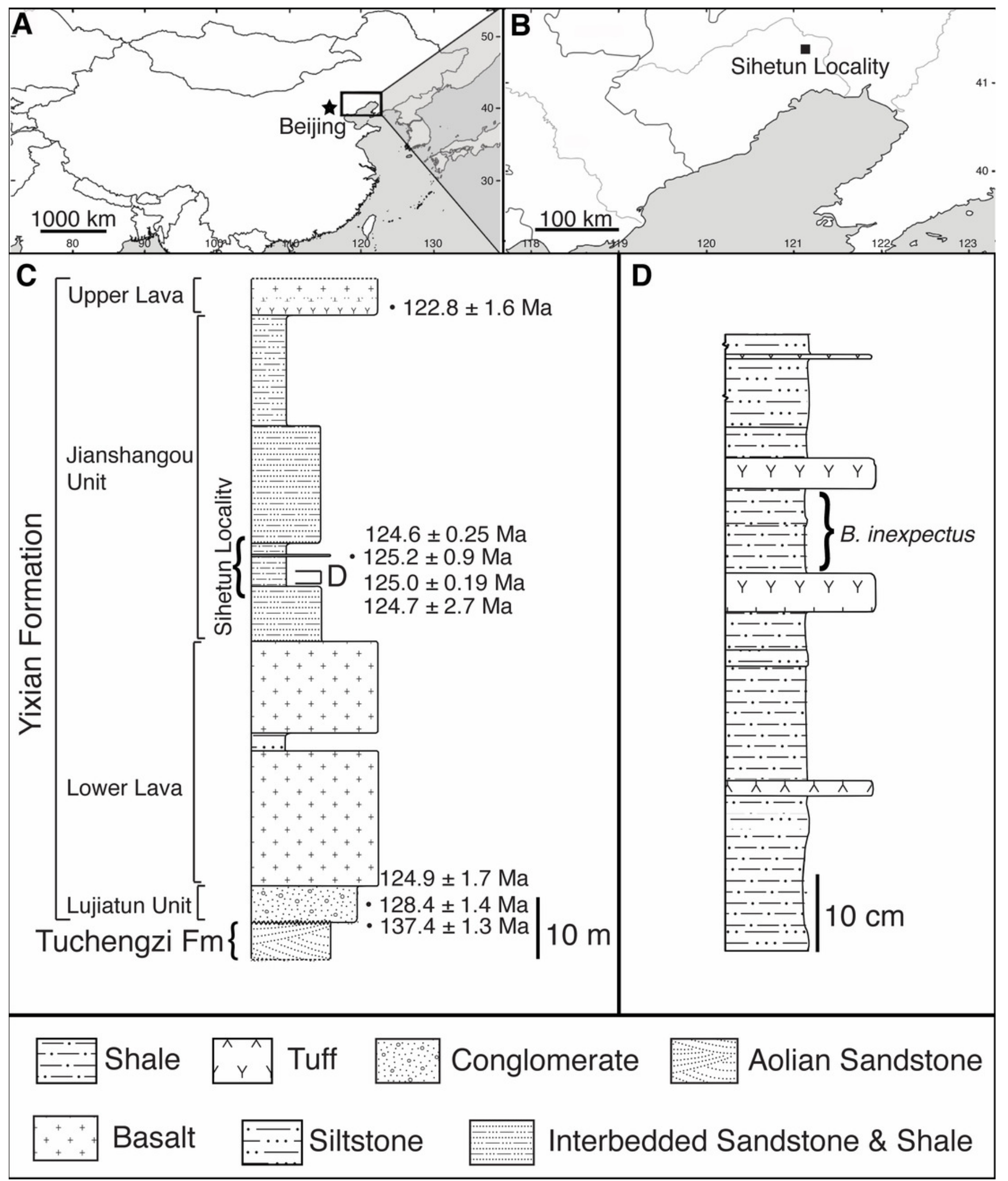




\section{Figure 2}

Photograph of sampled specimen (Beipiaosaurus inexpectus, IVPP V11559) and transmitted light micrographs of representative thin sections

Figure 2. Photograph of sampled specimen (Beipiaosaurus inexpectus, IVPP V11559) (A) and transmitted light micrographs of representative thin sections (B-D). In thin section images, black arrows indicate spheres (putative red blood cells), white arrows indicate osteocyte lacunae, and grey arrows indicate non-spherical vessel fills $\mathbf{A}$ : Initially published portion of IVPP V11559, with sampled areas marked "1" and "2". Samples from these areas include previously published thin sections (Yao et al. 2002) as well as thin sections produced by the authors for this study. We also sampled fragments of associated gastralia (not pictured here) B: Vessel containing spheres as well as non-spherical amorphous vessel fill (grey bracket) in thin section LJ98B-1 (sample area 1; originally prepared for Yao et al., 2002). C: Spheres in an anastomosing vessel in thin section 2018-L2 (newly prepared thin section from sample area 2). D: Small grainy vessel fill, also from thin section LJ98B-1. 


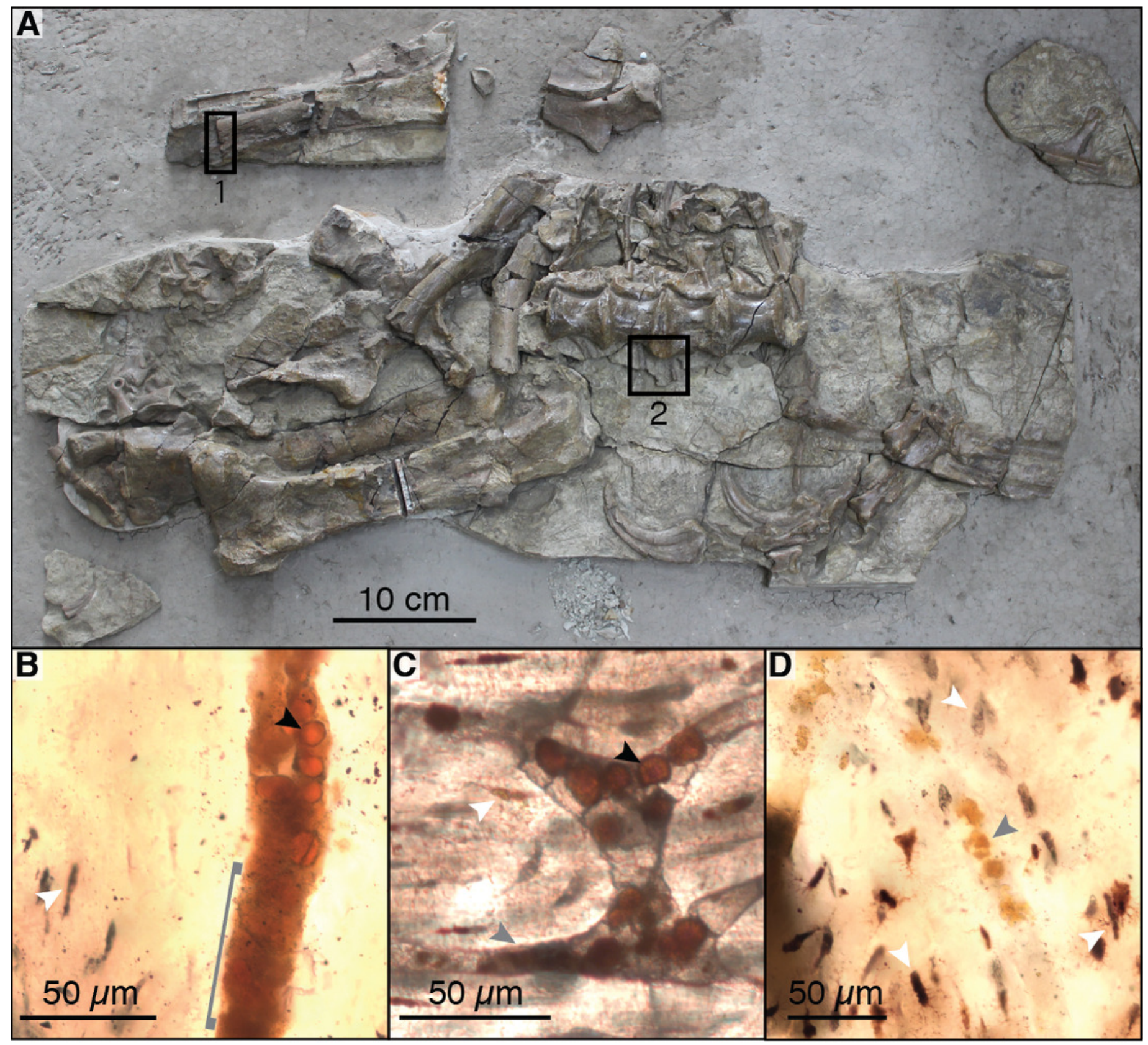




\section{Figure 3}

Raman spectra collected from thin sections 2018-L1 - 2018-L5 and from a modern alligator bone sample.

Figure 3. Raman spectra collected from thin sections 2018-L1 - 2018-L5 (gastralia fragment from Beipiaosaurus inexpectus, IVPP V11559) and from a modern alligator bone sample. Vertical bands represent approximate locations of the characteristic Raman peaks of pyrite, magnetite, and apatite. A-D (top panel): Examples of sample locations (blue dots) targeted for Raman spectroscopic analysis. These are not necessarily the spot analyzed, but serve to illustrate the type of morphological features selected for Raman analysis. A'-D' (bottom panel): Raman spectra corresponding to morphological features marked by blue dots in A-D (top panel). These spectra correspond to "2018_L2_784_pos2_indredorange2", "2018_L2_pos2_bone", "2018_L2_784_pos2_redfill", and "2018_L2_784_pos2_round4" in the supplementary data, respectively. Regardless of the morphological feature analyzed in this fossil, the Raman spectra show six peaks, with average wavenumbers of 962.4, 1212, 1296, 1430, 1570, and $1690 \mathrm{~cm}^{-1}$. E' (bottom panel): Raman spectrum of a modern alligator bone. Apatite is apparent throughout this thin section, whereas the iron-bearing minerals are not present. 


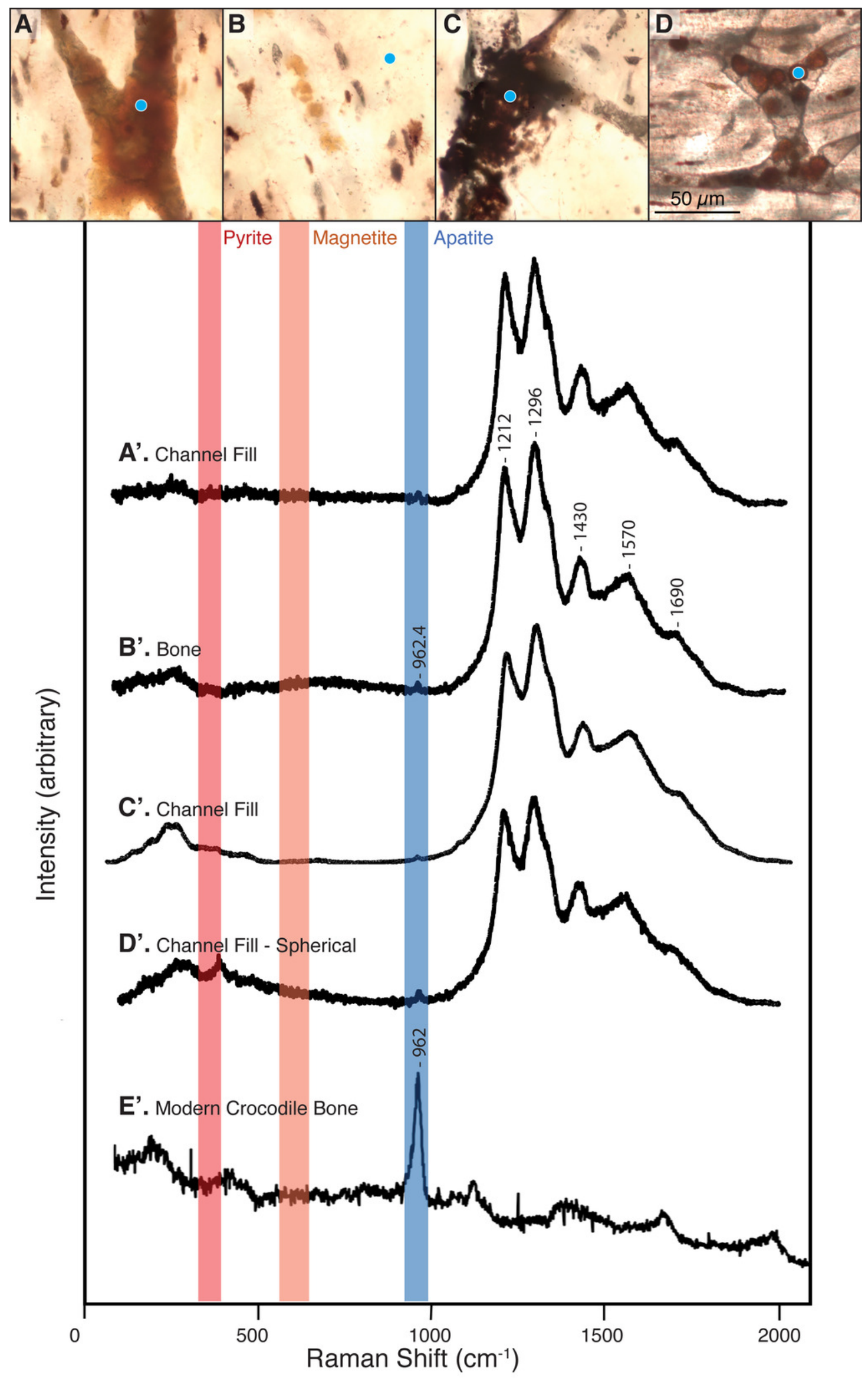


Figure 4

Transmitted light micrographs of petrified wood

Figure 4. Transmitted light micrographs of petrified wood from thin section 2018-1. A:

Spheres ranging in size from approximately $5-20 \mu \mathrm{m}$ are visible at low magnification (black arrows mark small and large examples). B: At higher magnification, the spheres appear to be made up of smaller crystals. 


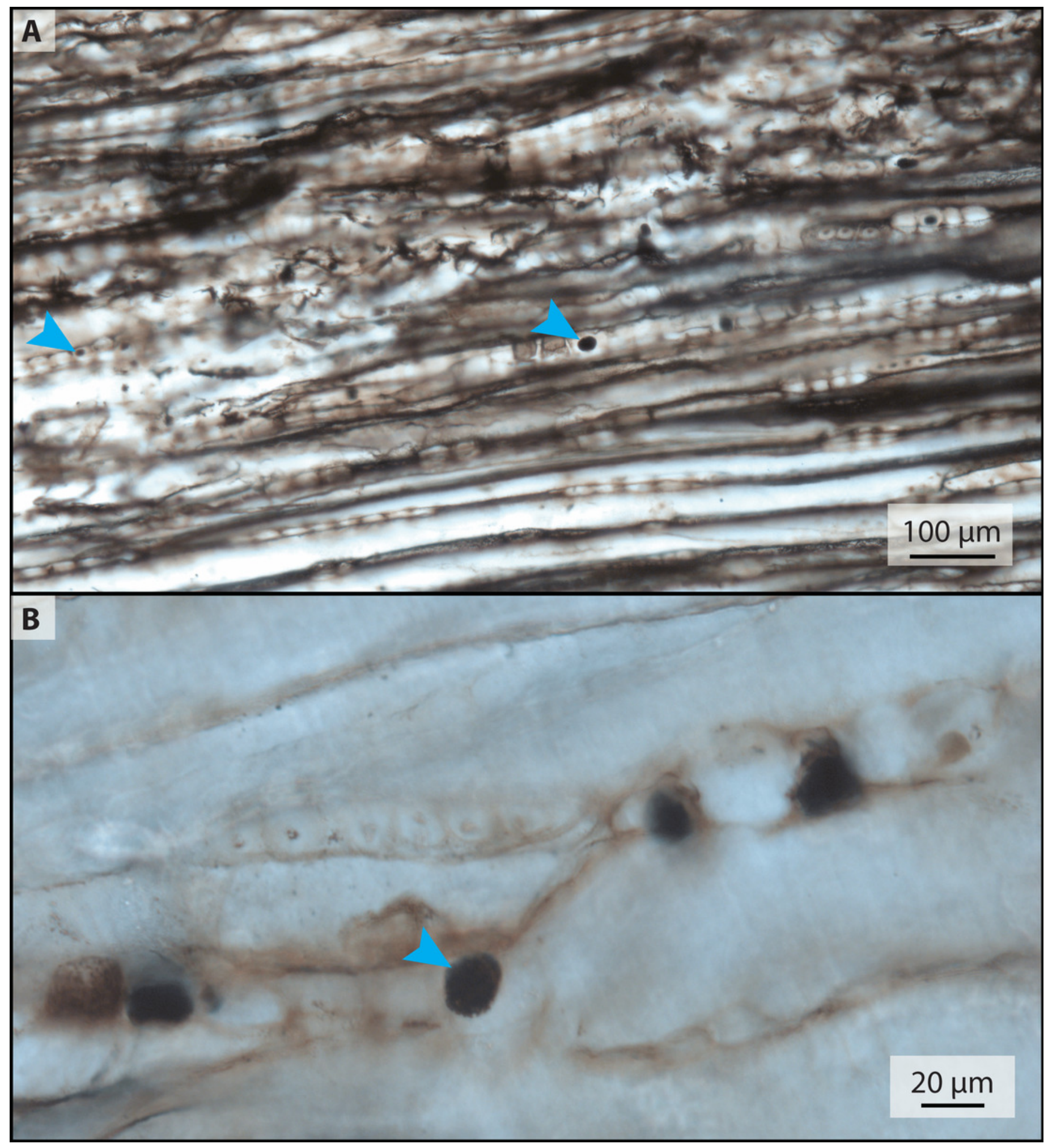




\section{Figure 5}

Energy Dispersive X-ray Spectroscopy (EDS) data from thin section 2018-L2.

Figure 5. Energy Dispersive X-ray Spectroscopy (EDS) data from thin section 2018-L2. A: Scanning electron micrograph of an area analyzed with EDS. B-F: EDS elemental maps of interest, with the mapped element marked in the lower left of each panel. Relative abundance of an element is indicated by color brightness. G: Spectrum of elements present across the whole analyzed area. H-I: SEM images of areas of 2018-L2 indicating EDS analysis points of vessel and lacuna fills. J: EDS summary results averaged across the three analysis points denoted in J-K, showing kaolinite filling a vessel and lacuna. Elemental ratios were calculated from atomic percentages. 

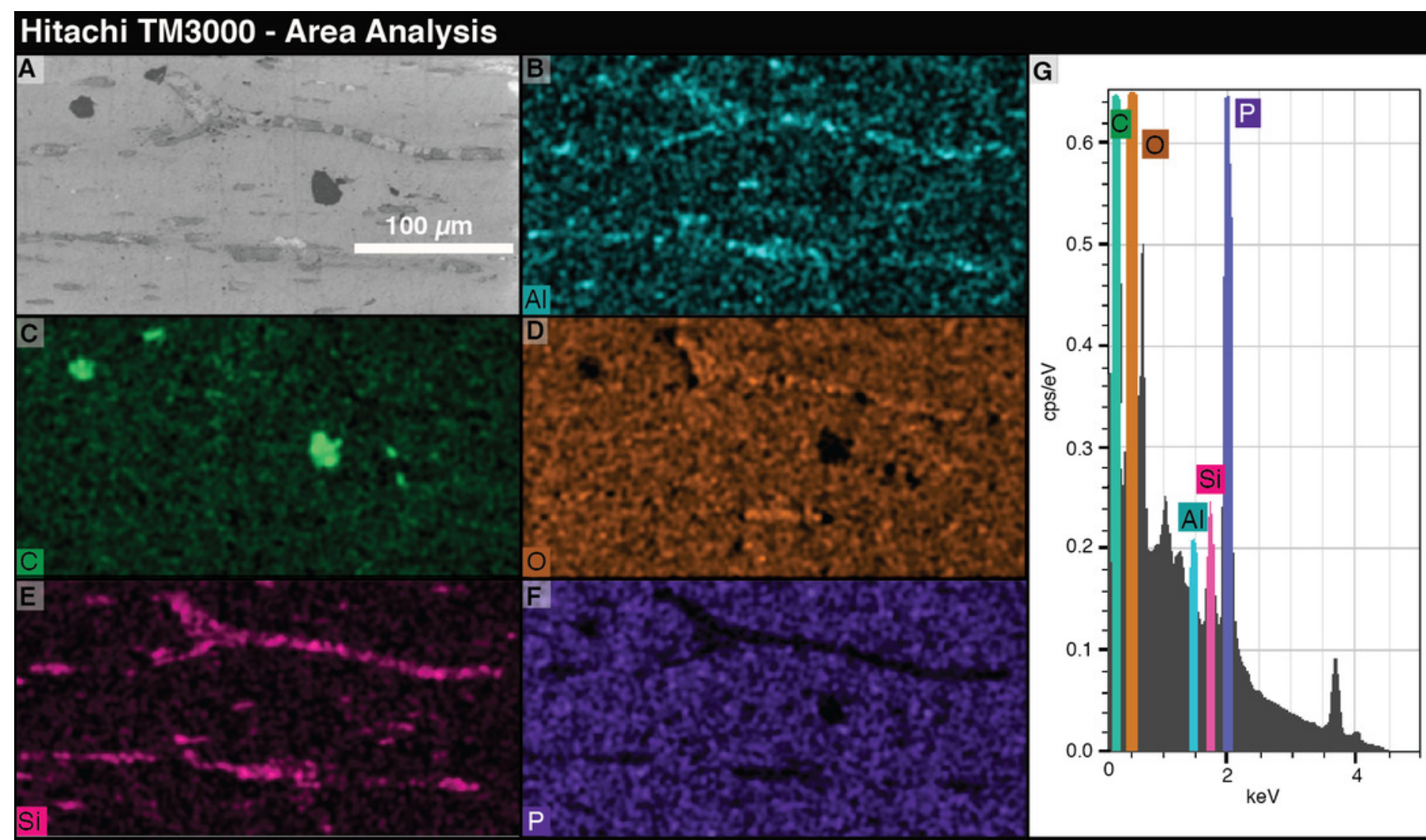

\section{Quanta 600FEG - Point Analyses}

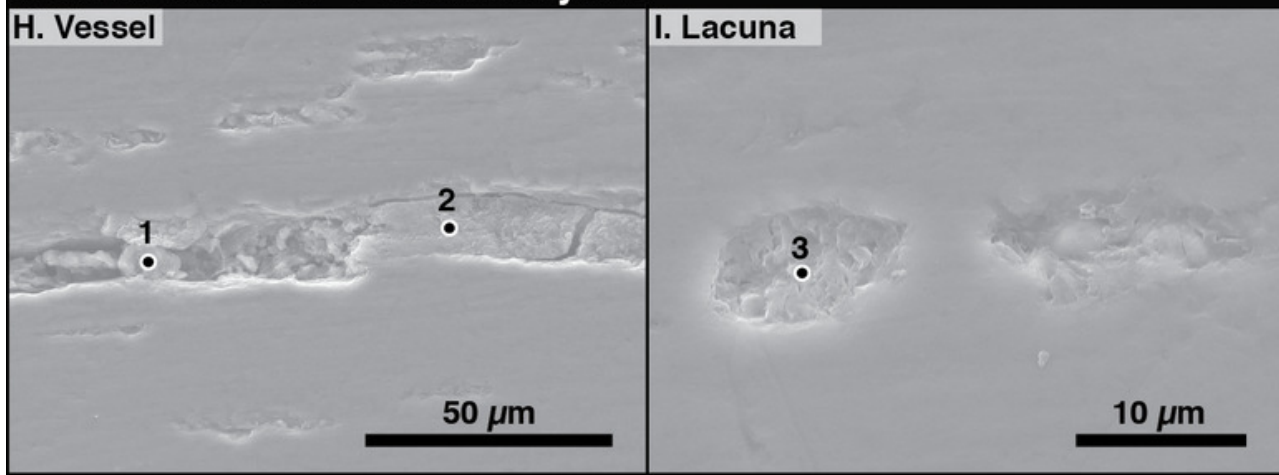

\begin{tabular}{|l|c|}
\hline$[\mathrm{Mg}+\mathrm{Fe}] / \mathrm{Mg}$ & 1 \\
\hline $\mathrm{Mg} / \mathrm{Al}$ & 0.362 \\
\hline$[\mathrm{Na}+\mathrm{K}] / \mathrm{Al}$ & 0.121 \\
\hline
\end{tabular}




\section{Figure 6}

Time of Flight Secondary lon Mass Spectrometry (TOF-SIMS) maps of an in situ bone fragment and the surrounding matrix, specimen 2018-X3.

Figure 6. Time of Flight Secondary lon Mass Spectrometry (TOF-SIMS) maps of an in situ bone fragment and the surrounding matrix, specimen 2018-X3. A: The cut fragment with cross section of a gastralium, fine lamination in surrounding shale, and an orange-tinted concretion. Examined area indicated by rectangle. B: Drawing of the scanned area emphasizing borders between bone, sedimentary matrix, and concretion. C: TOF-SIMS map of total chemical species, consisting of a collage of 21 half-millimeter squares. D-J: TOF-SIMS maps of six chemical species of interest, with the mapped chemical species noted in upper left of each panel. These six species represent a subset of the total collected species. 

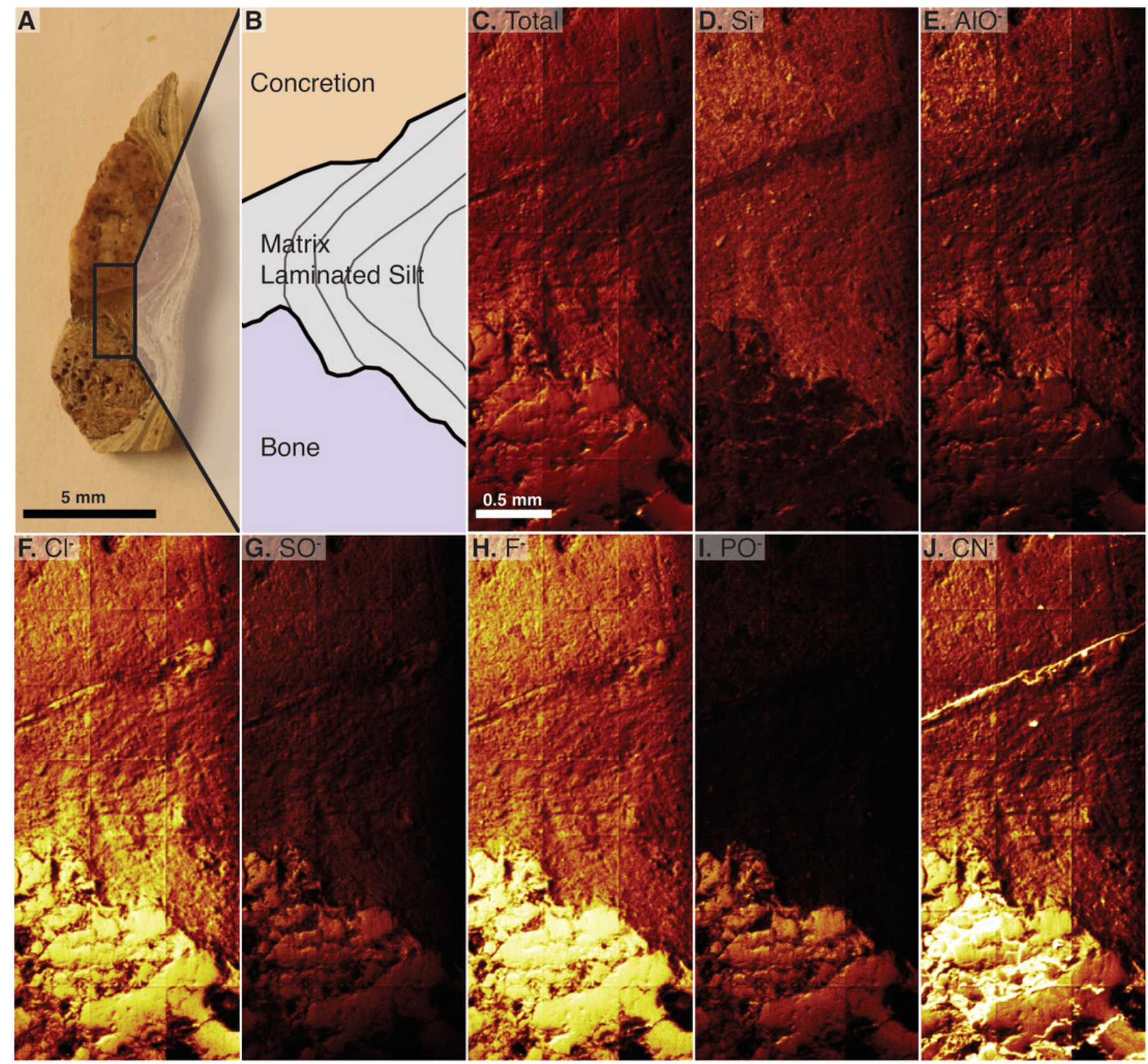


\section{Figure 7}

Schematic diagram showing the inferred diagenesis of $B$. inexpectus at a microscopic scale.

Figure 7. Schematic diagram showing the inferred diagenesis of $B$. inexpectus at a microscopic scale. All scalebars are $100 \mu \mathrm{m}$ A: Drawing reconstructed to a histologic view of the sectioned area of bone in life showing red and white blood cells in a vascular canal and lacunae populated by osteocytes. B: Post-mortem effects of lacustrine burial, cells lyse and the canal lining degrades as water fills the canals. C: Early diagenetic changes in anoxic sediment. Sulfate reducing microbes (depicted as orange) in the vessels facilitate pyrite formation (light grey). Diagenetic formation of kaolinite (grey) begins. D: Later diagenesis. Framboidal minerals are altered over time (grey) and entombed within authigenic kaolinite in various habits (beige and dark grey). Cation exchange occurs between the bone apatite and fluids. E: Transmitted light photomicrograph of a vessel in thin section, as it appears today. 


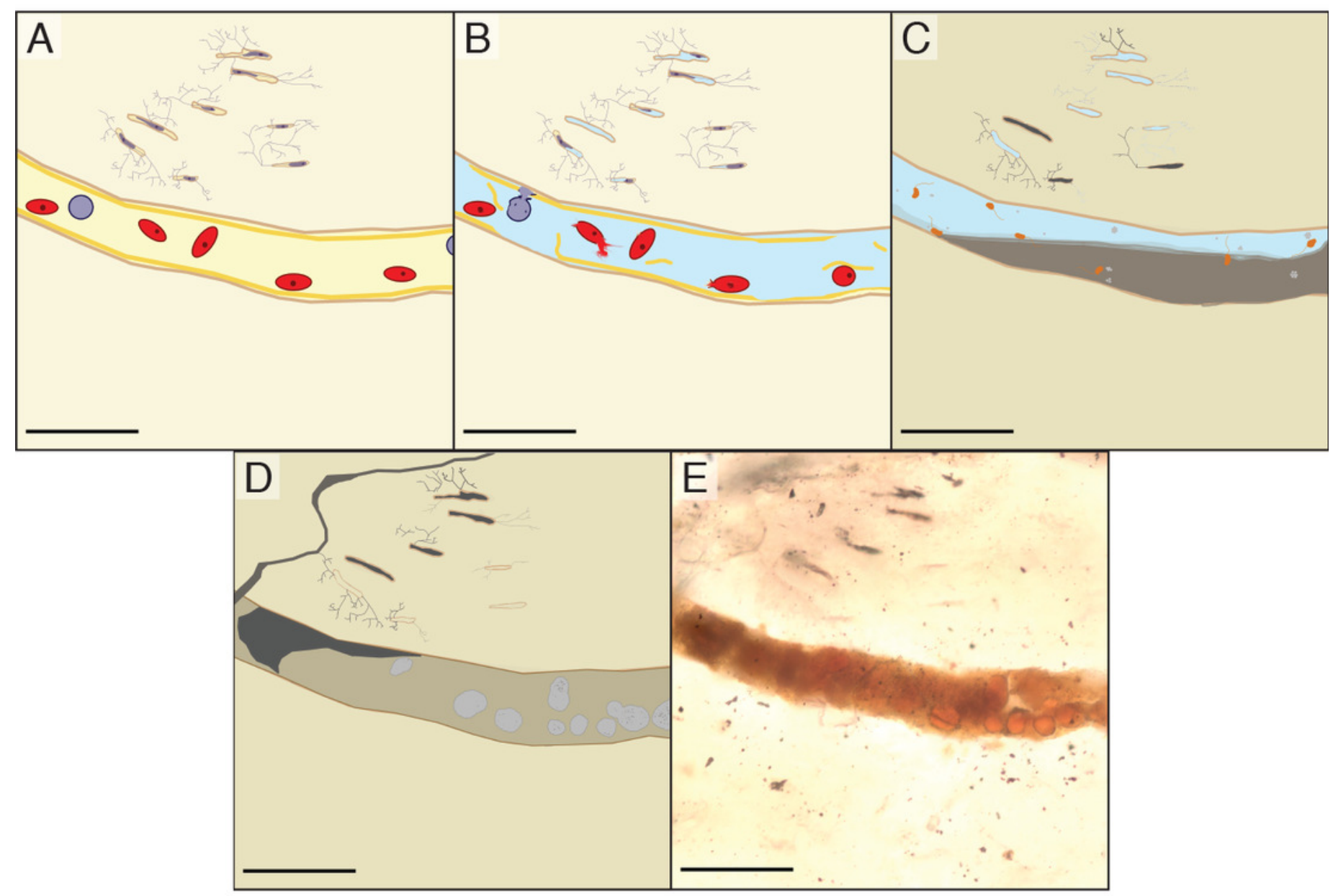




\section{Table $\mathbf{1}$ (on next page)}

Materials used in this study

Materials used in this study. All dinosaur material is from IVPP V11559 (holotype specimen of Beipiaosaurus inexpectus). Each specimen listed here was examined during this study, and its anatomical and preparatory context are listed in addition to the types of analyses used. Some were not part of the final results. 
Manuscript to be reviewed

\begin{tabular}{|c|c|c|c|c|c|c|c|}
\hline Specimen & Source & $\begin{array}{l}\text { Type of } \\
\text { Sample }\end{array}$ & Element & Position & Orientation & $\begin{array}{l}\text { Analyses } \\
\text { Conducted }\end{array}$ & $\begin{array}{l}\text { Locations Analyzed, } \\
\text { Raman }\end{array}$ \\
\hline 2018-X1 & $\begin{array}{l}\text { Prepared by authors from } \\
\text { materials provided by Yao, et al. }\end{array}$ & $\begin{array}{l}\text { Thin } \\
\text { Section }\end{array}$ & Gastralium & $\begin{array}{l}\text { near broken end } \\
\text { of } 2 \mathrm{~cm} \text { fragment }\end{array}$ & Transverse & histology & N/A \\
\hline $2018-X 2$ & $\begin{array}{l}\text { Prepared by authors from } \\
\text { materials provided by Yao, et al. }\end{array}$ & $\begin{array}{l}\text { Thin } \\
\text { Section }\end{array}$ & Gastralium & $\begin{array}{l}\text { serial section } \\
\text { from } 2018-\mathrm{X} 1\end{array}$ & Transverse & histology & N/A \\
\hline 2018-L1 & $\begin{array}{l}\text { Prepared by authors from } \\
\text { materials provided by Yao, et al. }\end{array}$ & $\begin{array}{l}\text { Thin } \\
\text { Section }\end{array}$ & Gastralium & $\begin{array}{l}\text { exterior, serial } \\
\text { section with 2018- } \\
\text { L2-5 }\end{array}$ & Longitudinal & $\begin{array}{l}\text { histology, } \\
\text { Raman, EDS }\end{array}$ & $\begin{array}{l}\text { bone, epoxy, } \\
\text { plexiglass, glue, } \\
\text { various vessel fills, } \\
\text { spheres, lacunae }\end{array}$ \\
\hline 2018-L2 & $\begin{array}{l}\text { Prepared by authors from } \\
\text { materials provided by Yao, et al. }\end{array}$ & $\begin{array}{l}\text { Thin } \\
\text { Section }\end{array}$ & Gastralium & $\begin{array}{l}\text { exterior, serial } \\
\text { section with } 2018 \text { - } \\
\text { L2-5 }\end{array}$ & Longitudinal & $\begin{array}{l}\text { histology, } \\
\text { Raman, EDS }\end{array}$ & $\begin{array}{l}\text { bone, epoxy, various } \\
\text { vessel fills, spheres, } \\
\text { lacunae }\end{array}$ \\
\hline 2018-L3 & $\begin{array}{l}\text { Prepared by authors from } \\
\text { materials provided by Yao, et al. }\end{array}$ & $\begin{array}{l}\text { Thin } \\
\text { Section }\end{array}$ & Gastralium & $\begin{array}{l}\text { exterior, serial } \\
\text { section with 2018- } \\
\text { L2-5 }\end{array}$ & Longitudinal & $\begin{array}{l}\text { histology, } \\
\text { Raman }\end{array}$ & $\begin{array}{l}\text { various vessel fills, } \\
\text { spheres }\end{array}$ \\
\hline 2018-L4 & $\begin{array}{l}\text { Prepared by authors from } \\
\text { materials provided by Yao, et al. }\end{array}$ & $\begin{array}{l}\text { Thin } \\
\text { Section }\end{array}$ & Gastralium & $\begin{array}{l}\text { exterior, serial } \\
\text { section with 2018- } \\
\text { L2-5 }\end{array}$ & Longitudinal & $\begin{array}{l}\text { histology, } \\
\text { Raman }\end{array}$ & $\begin{array}{l}\text { various vessel fills, } \\
\text { spheres }\end{array}$ \\
\hline 2018-L5 & $\begin{array}{l}\text { Prepared by authors from } \\
\text { materials provided by Yao, et al. }\end{array}$ & $\begin{array}{l}\text { Thin } \\
\text { Section }\end{array}$ & Gastralium & $\begin{array}{l}\text { exterior, serial } \\
\text { section with 2018- } \\
\text { L2-5 }\end{array}$ & Longitudinal & $\begin{array}{l}\text { histology, } \\
\text { Raman }\end{array}$ & $\begin{array}{l}\text { various vessel fills, } \\
\text { spheres }\end{array}$ \\
\hline HO-9601 & Prepared by Yao, et al. & $\begin{array}{l}\text { Thin } \\
\text { Section }\end{array}$ & Humerus & unknown & Longitudinal & histology & N/A \\
\hline HO-9602 & Prepared by Yao, et al. & $\begin{array}{l}\text { Thin } \\
\text { Section }\end{array}$ & Humerus & shaft & Transverse & histology & N/A \\
\hline LJ98B-1 & Prepared by Yao, et al. & $\begin{array}{l}\text { Thin } \\
\text { Section }\end{array}$ & Humerus & unknown & Longitudinal & histology & N/A \\
\hline LJ98B-4 & Prepared by Yao, et al. & $\begin{array}{l}\text { Thin } \\
\text { Section }\end{array}$ & Humerus & shaft & Transverse & histology & N/A \\
\hline
\end{tabular}


1

\begin{tabular}{|l|l|l|l|l|l|l|l|} 
2018-1 & $\begin{array}{l}\text { Prepared by authors from } \\
\text { materials provided by Yao, et al. }\end{array}$ & $\begin{array}{l}\text { Thin } \\
\text { Section }\end{array}$ & $\begin{array}{l}\text { Petrified } \\
\text { Wood }\end{array}$ & N/A & para-transverse & histology & N/A \\
\hline 2018-X3 & $\begin{array}{l}\text { Prepared by authors from } \\
\text { materials provided by Xu }\end{array}$ & $\begin{array}{l}\text { Thick } \\
\text { Section } \\
\text { from Hand } \\
\text { Sample }\end{array}$ & Gastralium & $\begin{array}{l}\text { near break, } \\
\text { central in element }\end{array}$ & Transverse & TOF-SIMS & N/A \\
\hline Alligator & Provided by Stocker & $\begin{array}{l}\text { Unprepared } \\
\text { bone }\end{array}$ & Rib & exterior & N/A & Raman & bone matrix \\
\hline
\end{tabular}

2 Table 1. Materials used in this study. All dinosaur material is from IVPP V11559 (holotype specimen of Beipiaosaurus inexpectus).

3 Each specimen listed here was examined during this study, and its anatomical and preparatory context are listed in addition to the

4 types of analyses used. Some were not part of the final results. 